\title{
TRAF3 Gene
}

National Cancer Institute

\section{Source}

National Cancer Institute. TRAF3 Gene. NCI Thesaurus. Code C96377.

This gene is involved in both signal transduction and apoptosis regulation. 